\title{
Epidemiology of scabies in relation to socio-economic and selected climatic factors in north-east Poland
}

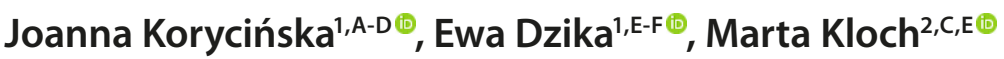 \\ ${ }^{1}$ Department of Medical Biology, Faculty of Health Sciences, University of Warmia and Mazury (UWM), Olsztyn, Poland \\ 2 Department of Animal Genetics and Breeding, Faculty of Animal Sciences, Warsaw University of Life Sciences (SGGW), \\ Warsaw, Poland \\ A - Research concept and design, B - Collection and/or assembly of data, C - Data analysis and interpretation,
}

$D$ - Writing the article, E-Critical revision of the article, F- Final approval of article

Korycińska J, Dzika E, Kloch M. Epidemiology of scabies in relation to socio-economic and selected climatic factors in north-east Poland. Ann Agric Environ Med. 2020; 27(3): 374-378. doi: 10.26444/aaem/109319

\section{Abstract}

Introduction. Scabies is a contagious parasitic disease, a skin infestation caused by Scaroptes scabieri, tiny mites that burrow under the skin. Outbreaks of scabies can be difficult to control and require the implementation of appropriate control programme.

Objective. The purpose of the study was to analyze the epidemiology of scabies in north-east Poland, considering socioeconomic and selected climatic factors.

Materials and method. The analysis was based on data reports $(n=26,362)$ obtained from the Polish National Health Fund (NFZ) for the period 2007-2014. Monthly climate data were collected from the Institute of Meteorology and Water Management/National Research Institute (IMGW-PIB) in Warsaw, including data on temperature and relative humidity. Additionally, the influence of socio-economic factors on the prevalence of scabies was analyzed. Data on population size, medical staff, and unemployment rate were obtained from the Central Statistical Office (GUS) in Warsaw, and analyzed using SPSS Statistics 24.0 programme.

Results. The age group of 10-19 years showed the highest infestation rates. Seasonality of scabies was demonstrated. The highest numbers of cases were reported during the autumn and winter months. There was a significant negative correlation $(r h o=-0.499 ; p<0.001)$ between air temperature and the incidence of scabies, and a positive correlation $(r=0.532 ; p<0.001)$ between relative humidity and the number of cases reported. A rise in the unemployment rate also caused an increase in the scabies incidence rate $(r=0.294 ; p<0.001)$.

Conclusions. The results suggest that an improvement of socio-economic conditions may contribute to a reduction in the number of scabies infections. The possibility should be considered of monitoring the parameters, such as air temperature and humidity, particularly when scabies outbreaks occur.

Key words

scabies, epidemiology, socio-economic characteristic, climate factors

\section{INTRODUCTION}

Scabies is a global disease caused by Sarcoptes scabiei. It is a cosmopolitan obligatory human skin parasite [1]. Each year about 300 million cases are reported worldwide [2]. However, a lack of uniform reporting system of the disease makes it difficult to assess the scale of the problem. Epidemiological data are based on various data sources, comprising national reporting systems, military databases or institutional settings, such as schools, hospitals or care facilities [3]. In 2013, scabies was placed on the list of Neglected Tropical Diseases by the World Health Organization (WHO) [4], and in 2011 the International Alliance for the Control of Scabies (IACS) was formed, bringing together professionals from across the globe [5].

Although the disease affects all social classes, some groups, such as children, the elderly, immunocompromised individuals, the residents of care facilities or overcrowded populations with low socio-economic status, are particularly

Address for correspondence: Joanna Korycińska, Department of Medical Biology Faculty of Health Sciences, University of Warmia and Mazury (UWM), Olsztyn, Poland joanna.korycinska@uwm.edu.pl

Received: 20.03.2019; accepted: 08.05.2019; first published: 11.06 .2019 at risk of becoming infected [3]. A classic symptom of scabies is intense pruritus, becoming particularly intense at night. Depending on the stage of the disease and inflammatory response, the clinical symptoms may vary [6]. Diagnostically relevant lesions are those with a typical irregular tunnel, a few millimeters to a few centimeters long, formed by the female mite $[7,8]$. The infection spreads through direct contact with an infected person or indirectly through fomites. Transmission can also occur during sexual contacts with an infected individual [9]. Due to the high infectivity of scabies, it is essential that all family members undergo treatment, as will all other people having direct contact with an infected person. Otherwise, the scabies-infected individuals, while not yet showing the symptoms of the disease, may still infect people in their immediate surroundings [6].

In the research conducted to-date, too little attention has been paid to analysis of the distribution of scabies incidence, and in particular to the seasonal dynamics of scabies occurrence with reference to air temperature and humidity. Laboratory tests indicate that high relative air humidity coupled with low temperature results in a longer survival time of scabies $[10,11]$. The key element in the transmission of the disease is the ability of scabies to survive 
and retain infectivity in the external environment, outside the host body.

To-date, only one paper has been published containing a more detailed epidemiological analysis of scabies, covering the years 1990-1998 in the Świętokrzyskie Region of Poland [12]. Other papers have dealt with selected aspects of human populations, containing analysis of scabies prevalence in Lower Silesian Region [13] and the Polish cities of Katowice [14] and Łódź [15]. It should be emphasized that most of these papers are based on epidemiological reports from State Sanitary-Epidemiological Stations in Poland. The implementation of the Act of 5 December 2008 on Preventing and Fighting Infections and Infectious Diseases in Humans, Journal of Laws, No. 234, item 1570, excluded scabies from the list of notifiable communicable diseases which must be registered by District Sanitary-Epidemiological Stations.

Due to the fact that no other source of data was available which could be used to assess the scale of the problem in the Warmińsko-Mazurskie Province of north-east Poland, the analysis was conducted on the basis of data obtained from Warmińsko-Mazurskie Branch of the National Health Fund (NFZ) in Warsaw. As indicate in studies by other authors, the NFZ data provide a solid basis for conducting research $[16,17,18]$. The lack of data for the last several years on the epidemiological situation regarding scabies dictates a need to bring our knowledge in that respect up-to-date.

\section{OBJECTIVES}

The purpose of the study was to analyze the epidemiology of scabies in north-east Poland, considering socio-economic and selected climatic factors.

\section{MATERIALS AND METHOD}

Data source and collection. The analysis was based on data reports obtained from Warmińsko-Mazurski Branch of the National Health Fund (NFZ), according to the International Statistical Classification of Diseases and Related Health Problems (ICD-10: B86). The research covered the period 2007-2014 in the Warmińsko-Mazurskie Province. The data included: patient number, age, gender, patient's place of residence (rural areas, rural commune, urban commune, town) and the date of scabies presentation.

Selected climatic factors for 2007-2012 covering mean monthly temperatures (in ${ }^{\circ} \mathrm{C}$ ) and relative air humidity (in \%) were retrieved from the Institute of Meteorology and Water Management from six weather stations: Elbląg, Kętrzyn, Olsztyn, Mikołajki, Lidzbark Warmiński and Gołdap, located in the Warmińsko-Mazurskie Province (Tab. 1). The data on population size, medical staff (nurse, doctor), and the unemployment rate were obtained from the Central Statistical Office (GUS) in Warsaw.

This was a retrospective study and all data submitted for analysis were rendered anonymous. No Ethical Committee approval was required as the study was non-invasive and used data collected by a public institution.

Data analysis. The data collected served to determine the number of scabies infections, considering the unit of administrative division (town, urban commune, rural
Table 1. Average monthly meteorological factors in north-east Poland, 2007-2012

\begin{tabular}{lcccccc}
\hline \multirow{2}{*}{ Month } & \multicolumn{3}{c}{ Temperature $\left({ }^{\circ} \mathrm{C}\right)$} & \multicolumn{3}{c}{ Relative humidity (\%) } \\
\cline { 2 - 7 } & Mean & Maximum & Minimum & Mean & Maximum & Minimum \\
\hline January & -2.5 & 8.0 & -10.2 & 87.8 & 94.4 & 79.2 \\
\hline February & -3.5 & 3.6 & -8.9 & 84.7 & 94.3 & 79.4 \\
\hline March & 2,9 & 7.0 & 0.6 & 78.9 & 90.1 & 71.0 \\
\hline April & 8.5 & 10.6 & 7.1 & 67.6 & 81.4 & 56.9 \\
\hline May & 12.8 & 14.3 & 11.2 & 72.1 & 83.5 & 66.2 \\
\hline June & 15.9 & 18.1 & 14.3 & 74.4 & 84.7 & 61,6 \\
\hline July & 18.6 & 21.4 & 16,9 & 77.7 & 85.1 & 71,1 \\
\hline August & 17.9 & 19.7 & 14.2 & 77.6 & 86.4 & 69.2 \\
\hline September & 13.2 & 14.8 & 6.6 & 81.0 & 89.8 & 76.0 \\
\hline October & 7.5 & 9.3 & 4.2 & 85.2 & 93.1 & 79.0 \\
\hline November & 4.0 & 5.8 & 0.5 & 91.3 & 95.9 & 86.2 \\
\hline December & -0.7 & 6.0 & -7.7 & 90.5 & 94.7 & 84.1 \\
\hline
\end{tabular}

commune, rural region). The prevalence of scabies was also determined for nine age groups $(0-9,10-19,20-29,30-39$, $40-49,50-59,60-69,70-79, \geq 80)$. Based on the number of medical consultations per one patient during the course of the disease, an analysis of incidence was conducted regarding patient gender and age. Time distribution of scabies incidence was conducted which covered the entire WarmińskoMazurskie Province during the period 2007-2014. The date considered was the date of the first contact of a patient with health care. The influence of temperature and relative air humidity on the seasonal dynamics of scabies was analyzed, with the analysis limited to the districts where the weather stations were located.

The influence of socio-economic factors in particular districts, such as the number of medical staff (nurse to patient ratio and doctor to patient ratio), as well as the unemployment rate on the incidence of scabies was also analyzed.

Statistical analysis was performed using SPSS Statistics 24.0 computer programme. The level of statistical significance was adopted as $\mathrm{p}<0.05$. In order to assess the significance of differences in the distribution of incidence between the groups, contingency Tables with chi-square tests were used.

Descriptive statistics were also used in the analysis (mean, median, standard deviation, minimum, maximum). Spearman's and Pearson's correlation coefficients were used to assess the relationship between the variables (depending on whether they conformed to the applicability rules). Student's t-test and U Mann-Whitney's test were used to compare the groups.

\section{RESULTS}

During the period 2007-2014, a total number of 26,362 cases of scabies were reported. The analysis did not show differences in the prevalence between women and men (54.7\% vs. $45.3 \%$; $\left.\mathrm{X}^{2}=9.263 ; \mathrm{p}=0.321\right)$. The analysis did show differences which were statistically significant in the prevalence of scabies depending on the patient age $\left(\mathrm{X}^{2}=184.09 ; \mathrm{p}<0.000\right)$. The number of cases decreased with patient age. The highest number of infected individuals belonged to the age group 1019 years $(25.9 \% ; \mathrm{n}=6817)$, followed by those representing the $0-9$ age group $(22.4 \% ; \mathrm{n}=5895)$ and those aged $20-29(15.6 \%$; $\mathrm{n}=4113$ ). Considering the units of administrative division, 
there were significant differences found in the incidence of scabies $\left(\mathrm{X}^{2}=206.30 ; \mathrm{p}<0.000\right)$. The highest numbers of the cases reported were in urban communes $(38.9 \% ; \mathrm{n}=10,264)$ and rural communes (31.5\%; $\mathrm{n}=8294)$ (Tab. 2).

Based on the number of medical consultations per one

Table 2. Demographic characteristics of patients with scabies in northeast Poland, 2007-2014

\begin{tabular}{|c|c|c|c|c|}
\hline Characteristics & Cases & (\%) & $\mathrm{X} 2$ & $\mathrm{p}$-Value \\
\hline No. of Cases & 26,362 & 100 & & \\
\hline \multicolumn{5}{|l|}{ Age Group } \\
\hline $0-9$ & 5,895 & 22.4 & 184.09 & $0.000^{*}$ \\
\hline $10-19$ & 6,817 & 25.9 & & \\
\hline $20-29$ & 4,113 & 15.6 & & \\
\hline $30-39$ & 2,437 & 9.2 & & \\
\hline $40-49$ & 2,305 & 8.7 & & \\
\hline $50-59$ & 2,199 & 8.3 & & \\
\hline $60-69$ & 1,444 & 5.5 & & \\
\hline $70-79$ & 783 & 3.0 & & \\
\hline$\geq 80$ & 367 & 1.4 & & \\
\hline \multicolumn{5}{|l|}{ Gender } \\
\hline Female & 14,426 & 54.7 & 9.263 & 0.321 \\
\hline Male & 11,936 & 45.3 & & \\
\hline \multicolumn{5}{|l|}{ Residence } \\
\hline Rural areas & 3,767 & 14.3 & 206.30 & $0.000^{*}$ \\
\hline Rural commune & 8,294 & 31.5 & & \\
\hline Urban commune & 10,264 & 38.9 & & \\
\hline Town & 4,038 & 15.3 & & \\
\hline
\end{tabular}

" $p$-Value $<0.05$ considered significant; $X^{2}$ - Pearson chi-square test

patient during the therapy, an analysis of the course of the disease was conducted regarding the gender of the patients. The analysis was to determine whether the number of medical consultations differed between men and women. Statistical analysis showed statistically significant differences in the number of medical consultations $(\mathrm{p}<0.001)$. The median for both genders was 1 , which means that at least half of the men and women in the study attended not more than one doctor's appointment. The results for women ranged from 1-13 appointments, for men there was a wider range of results - 1-15. Men were found to have a greater number of appointments during the treatment than women (Tab. 3).

Table 3. Number of medical consultations during treatment regarding gender, 2007-2014

\begin{tabular}{|c|c|c|c|c|c|c|c|}
\hline Gender & Mean & Median & $\begin{array}{l}\text { Standard } \\
\text { deviation }\end{array}$ & $\begin{array}{l}\text { Mini- } \\
\text { mum }\end{array}$ & $\begin{array}{l}\text { Maxi- } \\
\text { mum }\end{array}$ & $\mathrm{N}$ & $\begin{array}{c}\text { U Mann-Whitney } \\
\text { test }\end{array}$ \\
\hline Female & 1.42 & 1.00 & 0.839 & 1 & 13 & 14426 & \multirow{3}{*}{$\begin{array}{c}p<0.001^{*} \\
U=83940256.500\end{array}$} \\
\hline Male & 1.48 & 1.00 & 0.937 & 1 & 15 & 11936 & \\
\hline Total & 1.45 & 1.00 & 0.885 & 1 & 15 & 26362 & \\
\hline
\end{tabular}

" p-Value $<0.05$ considered significant

Analysis of the seasonal occurrence of the incidence of scabies covered the whole territory of the WarmińskoMazurskie Province. Based on one sample Student's t-test, the analysis showed a clear seasonal pattern of scabies incidence. The highest incidence was reported in the autumn and winter months: October $(13.0 \%, \mathrm{t}=-7.738 ; \mathrm{p}<0.001)$, November $(11.2 \%, \mathrm{t}=-4.133 ; \mathrm{p}<0.002)$, January $(10.1 \%, \mathrm{t}=-2.458, \mathrm{p}<0.034)$ and September $(10.0 \%, \mathrm{t}=-2.256 ; \mathrm{p}<0.048)$. The smallest number of cases was reported in June $(4.6 \%, \mathrm{t}=5.465 ; \mathrm{p}<0.001)$ (Tab. 4).

Table 4. Seasonal trend of occurrence of scabies in north-east Poland, 2007 to 2014

\begin{tabular}{lcccc}
\hline \multirow{2}{*}{ Month } & \multirow{2}{*}{$\begin{array}{l}\text { No. of cases in the } \\
\text { month }\end{array}$} & $\begin{array}{c}\text { Average No. of cases } \\
\text { in remaining months }\end{array}$ & \multicolumn{2}{c}{ Student's t-test } \\
\cline { 5 - 6 } & 2,675 & $2,153.4$ & -2.458 & $0.034^{*}$ \\
\hline January & 2,382 & $2,180.1$ & -0.969 & 0.356 \\
\hline Mebruary & 2,177 & $2,198.1$ & 0.065 & 0.949 \\
\hline March & 1,927 & $2,221.4$ & 1.403 & 0.191 \\
\hline April & 1,386 & $2,270.6$ & 4.453 & $0.001^{*}$ \\
\hline May & 1,237 & $2,284.1$ & 5.465 & $0.001^{*}$ \\
\hline June & 1,465 & $2,263.4$ & 3.958 & $0.003^{*}$ \\
\hline July & 1694 & $2,242.6$ & 2.660 & $0.024^{*}$ \\
\hline August & 2,630 & $2,157.5$ & -2.256 & $0.048^{*}$ \\
\hline September & 3,438 & $2,084.1$ & -7.738 & $0.001^{*}$ \\
\hline October & 2,954 & $2,128.1$ & -4.133 & $0.002^{*}$ \\
\hline November & 2,398 & $2,178.6$ & -1.025 & 0.329 \\
\hline December & & & &
\end{tabular}

"p-Value $<0.05$ considered significant

The analysis also included the influence of temperature and relative air humidity on the seasonal dynamics of the incidence of scabies. The territory of north-east Poland lies in a moderate climate zone. The average monthly data for the meteorological factors from 2007-2012 are shown in Table 1. The average monthly temperature was the highest $\left(18.6^{\circ} \mathrm{C}\right)$ in July and the lowest $\left(-3.5^{\circ} \mathrm{C}\right)$ in February. The average monthly relative air humidity ranged between $67.6-91.3 \%$. Correlations between the seasonal climate parameters and scabies are shown in Table 5.

Table 5. Correlation of climate factors to scabies in north-east Poland, 2007-2012

\begin{tabular}{lcl}
\hline Climate factors & Correlation & p-Value \\
\hline Temperature $\left({ }^{\circ} \mathrm{C}\right)$ & $-0.499^{\mathrm{a}}$ & $<0.001^{*}$ \\
\hline Relative humidity $(\%)$ & $0.532^{\mathrm{b}}$ & $<0.001^{*}$ \\
\hline p-Value $<0.05$ considered significant & &
\end{tabular}

a-Spearman Rho correlation; b- Pearson's correlation

Analysis of correlation showed a statistically significant negative correlation between air temperature and incidence (rho=-0.499; $\mathrm{p}<0.001)$. When the mean monthly air temperature fell, the number of cases increased. There was also a statistically significant positive correlation between air humidity and scabies incidence $(r=0.532 ; \mathrm{p}<0.001)$. Together with the increasing mean monthly air humidity, the monthly number of infections increased.

Another factor studied was the influence of particular socio-economic factors, such as the patient to medical staff ratio (nurses, doctors) and the unemployment rate on the occurrence of the disease (Tab. 6). The results obtained $(\mathrm{r}=0.294 ; \mathrm{p}<0.001)$ for the unemployment rate show that the increase in this variable was accompanied by an increase in the value of the incidence rate of scabies. However, for the relationship between medical staff to patient ratio and the incidence rate, no correlation was found between the variables $(\mathrm{p}>0.05)$. 
Table 6. Correlation of socio-economic factors to incidence rate for scabies in north-east Poland, 2007-2014

\begin{tabular}{lcc}
\hline Socio-economic factors & Correlation & p-Value \\
\hline Medical staff-physicians & $-0.078^{\mathrm{a}}$ & 0.345 \\
\hline Medical staff-nurses & $-0.061^{\mathrm{a}}$ & 0.461 \\
\hline Unemployment rate (\%) & $0.294^{\mathrm{b}}$ & $<0.001^{*}$ \\
\hline
\end{tabular}

p-Value $<0.05$ considered significant

a - Spearman Rho correlation; b- Pearson's correlation

\section{DISCUSSION}

This study and literature data show that scabies continues to represent a health threat for society in Poland, as well as globally. During the analyzed period in north-east Poland, a rise in the incidence of scabies was observed. The study indicated that the highest number of cases was reported in urban and rural communes. In Egypt and Iran, a higher incidence was seen in the rural communes $[19,20]$. This phenomenon may be due to the worse sanitary, hygiene and economic conditions of the rural population. It may also be caused by a more limited access to health care, as well as a lower level of health education [21]. In contrast, in the United Kingdom, more cases were reported in urban settings [22]. The current analysis shows that women tended to be affected by scabies slightly more often (54.7\%) than men (45.3\%), but it was not statistically significant. Similar results were obtained for south-east Poland [12]. However, in Cameroon and on the Solomon Islands there were more infections reported in boys, while in the United Kingdom - women [23, 24, 25].

In the current study, the highest prevalence was seen in the $10-19$ age group (25.9\%), followed by 0-9 (22.4\%) and 20-29 age groups (15.6\%). In other regions of Poland and around the world, the majority of cases were also reported in the first three age groups $[13,20,25]$. In the countries where scabies is an endemic disease the highest prevalence is seen in the youngest children [26,27]. These results seem to support the hypothesis that infections occur more often in these groups due to a greater degree of socialisation and more frequent personal contact [25].

In the current study, a significant seasonality trend was observed in the incidence of scabies. The highest number of cases were reported in the autumn and winter months, with a total of 11,697 (44.4\%) out of all the 26,362 cases. Likewise, the observations of other authors confirm a higher incidence in the cooler months $[12,20,28,29]$. This phenomenon can be partially explained by the fact that during the months with lower temperatures, people tend to share small spaces which promotes personal contacts [28]. A higher incidence of scabies during the winter period may also be influenced by greater sexual activity [30].

In countries of the tropical and subtropical climate zones there are no clear seasonal variations in the incidence of scabies, as confirmed by data from Brazil, Gambia, Malawi and Taiwan $[31,32,33,34]$. This phenomenon may result from the fact that in the countries where seasonal changes were observed the climate shows clear division into seasons, unlike in the countries of tropical and subtropical climate zones, where during the year there is a positive heat balance with a slowly changing temperature gradient.

The ability of Sarcoptes scabiei to survive and retain infectivity in the external environment, outside the body of the host, is a crucial factor in the transmission of scabies. Laboratory tests show that high relative air humidity in combination with low temperature contributes to a longer survival time of the mites outside the host body [10]. A similar situation was observed in the presented study. A statistically significant negative correlation was demonstrated between the air temperature and a positive correlation between the mean monthly relative air humidity and the number of scabies infections. In Taiwan, these two climate parameters also had a significant influence on the incidence of infections [34].

The relationship between socio-economic conditions and scabies infection is complex. This study shows that the rise in the unemployment rate was associated with a higher incidence rate of scabies. Previous studies also show a relationship between family income and prevalence of the disease $[12,13,35]$. In Bangladesh, in families with low income, activities such as washing clothes and bed linen, bathing, and the use of soap are less frequent than in families in a better financial situation [36]. Moreover, poor socioeconomic conditions directly affect the body nutritional status, which may in turn result in impaired immunity, and thus make it more difficult to fight the disease [37].

Many authors point to the fact that in economically developed countries the lower prevalence of scabies is to a large extent connected with making a quick and accurate diagnosis [38]. Epidemiological outbreaks often occur in hospital wards or care facilities, where the standards of hygiene are high $[39,40]$. In the current study, no correlation was found between the medical staff to patient ratio and the incidence rate. Similar results were obtained in the studies conducted by Buczek and Edison [12, 41].

\section{CONCLUSIONS}

This study, conducted on the basis of the number of medical consultations per one patient, shows that $70 \%$ of both men and women attended not more than one appointment in the course of treatment. However, the scale of the problem is noteworthy, as is the number of appointments made. The right diagnostics followed by optimal treatment will make it possible to limit the financial expenditure connected with medical consultations and treatment. Improvement in the epidemiological situation of scabies undoubtedly depends on the improvement of socio-economic conditions. The possibility of monitoring parameters such as temperature and air humidity should be considered, particularly if there are scabies outbreaks in institutional settings, such as hospitals or care facilities. It is also of great importance to educate the public about the rules of hygiene and to observe hygiene standards, as required in the case of diagnosing scabies.

\section{REFERENCES}

1. Hay RJ, Steer AC, Engelman D, et al. Scabies in the developing world-its prevalence, complications, and management. Clin Microbiol Infect. 2012; 18(4): 313-323.

2. Hengge UR, Currie BJ, Jäger G, et al. Scabies: a ubiquitous neglected skin disease. Lancet Infect Dis. 2006; 6(12): 769-779.

3. Mounsey KE, McCarthy JS, Walton SF. Scratching the itch: new tools to advance understanding of scabies. Trends Parasitol. 2013; 29(1): 35-42.

4. Thomas J, Peterson GM, Walton SF, et al. Scabies: an ancient global disease with a need for new therapies. BMC Infect Dis. 2015; 15(250): $1-6$. 
5. Engelman D, Kiang K, Chosidow O, et al. Toward the Global Control of Human Scabies: Introducing the International Alliance for the Control of Scabies. PLoS Negl Trop Dis. 2013; 7(8): 2167-2169.

6. Walton SF. The immunology of susceptibility and resistance to scabies. Parasite Immunol. 2010; 32(8): 532-540.

7. Chosidow O. Scabies. N Engl J Med. 2006; 354(16): 1718-1727.

8. Walton SF, Currie BJ. Problems in Diagnosing Scabies, a Global Disease in Human and Animal Populations. Clin Microbiol Rev. 2007; 20(2): 268-279.

9. Otero L, Varela JA, Espinosa E, et al. Sarcoptes scabiei in a sexually transmitted infections unit: a 15-year study. Sex Transm Dis. 2004; 31(12): 761-764.

10. Arlian LG, Runyan RA, Achar S, et al. Survival and infectivity of Sarcoptes scabiei var. canis and var. hominis. J Am Acad Dermatol. 1984; 11(2Pt1): 210-215

11. Mellanby K, Johnson CG, Bartley WC, et al. Experiments on the Survival and Behaviour of the Itch Mite, Sarcoptes scabiei DeG. var. hominis. Bull of Entomol Res. 1942; 33(4): 267-271.

12. Buczek A, Pabis B, Bartosik K, et al. Epidemiological study of scabies in different environmental conditions in central poland. Ann Epidemiol. 2006; 16(6): 423-428

13. Lonc E, Okulewicz A. Scabies and head-lice infestations in different environmental conditions of Lower Silesia, Poland. J Parasitol. 2000; 86(1): 170-171.

14. Sodowska H, Grygierczyk D. Zachorowania na świerzb wśród ludności miasta Katowice [Incidences of scabies among the population of the Katowice city]. Wiad Parazytol. 2000; 46 (4): 493-500. (in Polish)

15. Mamos AR, Osinska E. Wstępna ocena współczynnika zapadalności na świerzb w populacji łódzkiej [Preliminary analysis of the incidence rate of scabies in Łódz population]. Wiad Parazytol. 2001; 47(3): 365-369. (in Polish)

16. Raciborski K, Jahz-Rozyk K, Kłak A, et al. Epidemiology and direct costs of atopic dermatitis in Poland based on the National Health Fund register (2008-2017). Adv Dermatol Allergol. DOI: https://doi. org/10.5114/ada.2018.79099.

17. Śliwczyński A, Brzozowska M, Iltchew P, et al. Epidemiology of asthma in Poland in urban and rural areas, based on provided health care services. Pneumonol Alergol Pol. 2015; 83(3): 178-187.

18. Śliwczyński A, Tkacz A, Charliński G, et al. Zachorowalność i chorobowość na chłoniaka Hodgkina w Polsce na podstawie analizy danych Narodowego Funduszu Zdrowia z lat 2004-2010. [Incidence and morbidity for Hodgkin's lymphoma in Poland evaluated on the basis of data from the Polish National Health Insurer for the years 2004-2010]. Nowotw J Oncol. 2012; 62(3): 175-183. (in Polish)

19. Hegab DS., Kato AM, Kabbash IA, et al. Scabies among primary schoolchildren in Egypt: sociomedical environmental study in Kafr El-Sheikh administrative area. Clin Cosmet Investig Dermatol. 2015; 24(8): 105-111.

20. Nazari M, Azizi A. Epidemiological Pattern of Scabies and Its Social Determinant Factors in West of Iran. Health. 2014; 6(15): 1972-1977.

21. Romani L, Steer AC, Whitfeld MJ, et al. Prevalence of scabies and impetigo worldwide: a systematic review. Lancet Infect Dis. 2015; 15(8): 960-967.

22. Downs AM, Harvey I, Kennedy CT. The epidemiology of head lice and scabies in the UK. Epidemiol Infect. 1999; 122(3): 471-477.
23. Kouotou EA, Nansseu JRN, Kouawa MK, et al. Prevalence and drivers of human scabies among children and adolescents living and studying in Cameroonian boarding schools. Parasit Vectors. 2016; 9(400): 1-6.

24. Mason DS, Marks M, Sokana O, et al. The Prevalence of Scabies and Impetigo in the Solomon Islands: A Population-Based Survey. PLoS Negl Trop Dis. 2016; 10(6): 1-10.

25. Lassa S, Campbell MJ, Bennett CE. Epidemiology of scabies prevalence in the U.K. from general practice records. Br J Dermatol. 2011; 164(6): 1329-1334.

26. Clucas DB, Carville KS, Connors C, et al. Disease burden and healthcare clinic attendances for young children in remote aboriginal communities of northern Australia. Bull World Health Organ. 2008; 86(4): 275-281.

27. McMeniman E, Holden L, Kearns T, et al. Skin disease in the first two years of life in Aboriginal children in East Arnhem Land. Australas J Dermatol. 2011; 52(4): 270-273.

28. Savin JA. Scabies in Edinburgh from 1815 to 2000. J R Soc Med. 2005; 98(3): 124-129.

29. Mimouni D, Ankol OE, Davidovitch N, et al. Seasonality trends of scabies in a young adult population: a 20 -year follow-up. Br J Dermatol. 2003; 149(1): 157-159.

30. Wright R A, Judson FN. Relative and seasonal incidences of the sexually transmitted diseases. Atwo-year statistical review. Br J Vener Dis. 1987; 54(6): 433-440.

31. Heukelbach J, Wilcke T, Winter B, et al. Epidemiology and morbidity of scabies and pediculosis capitis in resource-poor communities in Brazil. Br J Dermatol. 2005; 153(1): 150-156.

32. Porter MJ. Seasonal change and its effect on the prevalence of infectious skin disease in a Gambian village. Trans R Soc Trop Med Hyg. 1990; 74(2): 162-168.

33. Kristensen JK. Scabies and Pyoderma in Lilongwe, Malawi. Prevalence and seasonal fluctuation. Int J Dermatol. 1991; 30(10): 699-702.

34. Liu JM, Wang HW, Chang FW, et al. The effects of climate factors on scabies. A 14-year population-based study in Taiwan. Parasite. 2016; 23(54): 1-7.

35. Inanir I, Sahin MT, Gündüz K, et al. Prevalence of skin conditions in primary school children in Turkey: differences based on socioeconomic factors. Pediatr Dermatol. 2002; 19(4): 307-311.

36. Karim SA, Anwar KS, Khan MA, et al. Socio-demographic characteristics of children infested with scabies in densely populated communities of residential madrashas (Islamic education institutes) in Dhaka, Bangladesh. Public Health. 2007; 121(12): 923-934.

37. Nair BK, Joseph A, Kandamuthan M. Epidemic scabies. Indian J Med Res. 1977; 65(4): 513- 518.

38. Hewitt KA, Nalabanda A, Cassell JA. Scabies outbreaks in residential care homes: factors associated with late recognition, burden and impact. A mixed methods study in England. Epidemiol Infect. 2015; 143(7): 1542-1551

39. Capobussi M, Sabatino G, Donadini A, et al. Control of scabies outbreaks in an Italian hospital: an information-centered management strategy. Am J Infect Control. 2014; 42(3): 316-320.

40. Suwandhi P, Dharmarajan TS. Scabies in the nursing home. Curr Infect Dis Rep. 2015; 17(453): 1-8.

41. Edison L, Beaudoin A, Goh L, et al. Scabies and Bacterial Superinfection among American Samoan Children, 2011-2012. PLoS One. 2015; 10(10): $1-10$. 